\title{
Article \\ Coordinated Expression of HPV-6 Genes with Predominant E4 and E5 Expression in Laryngeal Papilloma
}

\author{
Taro Ikegami ${ }^{1} ®$, Hitoshi Hirakawa ${ }^{1}$, Narutoshi Tsukahara ${ }^{2,3}$, Akikazu Murakami ${ }^{2,3}$, Norimoto Kise ${ }^{1}$, \\ Asanori Kiyuna ${ }^{1}$, Takayoshi Kosugi ${ }^{1}$, Shinya Agena ${ }^{1}$, Hidetoshi Kinjyo ${ }^{1}$, Narumi Hasegawa ${ }^{1}$, \\ Masatomo Touyama ${ }^{1}$, Shunsuke Kondo ${ }^{1}$, Hiroyuki Maeda ${ }^{1}$, Mikio Suzuki ${ }^{1, * \mathbb{D}}$ and Akira Ganaha ${ }^{1,4} \mathbb{D}$ \\ 1 Department of Otorhinolaryngology, Head and Neck Surgery, Graduate School of Medicine, \\ University of the Ryukyus, Okinawa 903-0215, Japan; ikegami@med.u-ryukyu.ac.jp (T.I.); \\ hanntagawa@hotmail.com (H.H.); norimoto7@gmail.com (N.K.); jibika_asanori97@yahoo.co.jp (A.K.); \\ tnq5@wildcats.unh.edu (T.K.); harugen3@yahoo.co.jp (S.A.); hidechanman223@yahoo.co.jp (H.K.); \\ br101426@gmail.com (N.H.); puyoraer99110@gmail.com (M.T.); kouhouiinn@yahoo.co.jp (S.K.); \\ maeidahiroyuki@yahoo.co.jp (H.M.); ganaha.akira.t8@cc.miyazaki-u.ac.jp (A.G.) \\ 2 Department of Parasitology \& Immunopathoetiology, Graduate School of Medicine, University of the Ryukyus, \\ Okinawa 903-0215, Japan; tsukahara@rephagen.com (N.T.); akimu@med.u-ryukyu.ac.jp (A.M.) \\ 3 RePHAGEN Co., Ltd., Okinawa 904-2234, Japan \\ 4 Department of Otolaryngology, Faculty of Medicine, University of Miyazaki, Miyazaki, \\ Miyazaki 889-1692, Japan \\ * Correspondence: suzuki@med.u-ryukyu.ac.jp; Tel.: +81-895-1183
}

\section{check for} updates

Citation: Ikegami, T.; Hirakawa, H.; Tsukahara, N.; Murakami, A.; Kise,

N.; Kiyuna, A.; Kosugi, T.; Agena, S.; Kinjyo, H.; Hasegawa, N.; et al.

Coordinated Expression of HPV-6

Genes with Predominant E4 and E5 Expression in Laryngeal Papilloma. Microorganisms 2021, 9, 520.

https://doi.org/10.3390/

microorganisms 9030520

Academic Editor: Tomokazu Yoshizaki

Received: 14 February 2021

Accepted: 27 February 2021

Published: 3 March 2021

Publisher's Note: MDPI stays neutral with regard to jurisdictional claims in published maps and institutional affiliations.

Copyright: (C) 2021 by the authors. Licensee MDPI, Basel, Switzerland. This article is an open access article distributed under the terms and conditions of the Creative Commons Attribution (CC BY) license (https:// creativecommons.org/licenses/by/ $4.0 /)$.
Abstract: Laryngeal papilloma (LP) associated with human papillomavirus (HPV)-6 or -11 infection shows aggressive growth. However, the detailed molecular mechanism of virus-driven tumorigenesis has not been uncovered fully. HPV-6 viral gene expression and dynamic alterations were investigated with in situ localization of viral DNA and RNA in 13 patients with HPV-6-infected laryngeal papilloma. The average viral load was $4.80 \times 10^{5} \pm 1.86 \times 10^{5}$ copies/ng DNA. E4, E5a, and $E 5 \mathrm{~b}$ mRNAs accounted for $96 \%$ of the expression of 9 mRNAs. The alteration of viral DNA load during recurrence paralleled the mRNA expression levels, and the expression of all mRNAs showed a similar curve. E4,E5a, and E5b were expressed in the middle to upper part of the epithelium and were co-expressed in the same cells. E4 immunohistochemistry demonstrated an extensively positive reaction in the upper cell layer in accordance with E4 mRNA expression. These results suggest that individual viral genes are coordinately expressed for viral replication, virus release, and immunosurveillance avoidance. The newly developed E4-specific monoclonal antibody can be applied to further functional studies and clinical applications such as targeted molecular therapies.

Keywords: laryngeal papilloma; human papillomavirus 6; viral lineage; viral mRNA expression; long-term alteration of viral load; anti-E4 monoclonal antibody

\section{Introduction}

Laryngeal papilloma (LP) is the most common benign epithelial tumor of the larynx, appearing as finger-like projections or multiple fronds of stratified squamous epithelium. The typical pathological findings are hyperplasia of basal cells and large vacuolated epithelial cells with clear cytoplasm. The estimated incidence of LP is approximately 4 per 100,000 in children and 2 per 100,000 in adults [1]. LP can form multiple tumors and has a high recurrence rate. Moreover, LP in children sometimes shows aggressive growth with rapid recurrence and tracheobronchial extension [2], although the malignant transformation of LP has been reported in less than $3 \%$ of cases $[3,4]$. Frequent surgery and occasional tracheostomies are needed to maintain the airway in some cases [2]. Since human papillomavirus (HPV)-6 and -11 infections are usually detected in LP, these viral infections are thought to be a distinct etiology of LP. 
HPVs are small double-stranded DNA viruses that infect mucosal and cutaneous epithelia and cause many tumorous lesions from benign warts to cancer of the anogenital and otolaryngological regions [5]. The approximately $8000 \mathrm{bp}$ HPV genome is divided into 3 regions, i.e., 6 early regions (E1,E2,E4,E5, E6, and E7), 2 late regions ( $L 1$ and $L 2)$, and the long control region (LCR). According to their association with cancer, HPV is divided into low-risk and high-risk types. HPV-6 and -11, observed in LP, are classified as the low-risk type. HPV preferentially infects mitotically active basal cells through microtears in the mucosal and cutaneous epithelium [6]. The viral life cycle synchronizes with the epithelial differentiation program, which may be due to the binding of differentially expressed cellular transcription factors to the LCR throughout the various epithelial layers [7]. Despite variation in the size and number of open reading frames, all papillomaviruses contain well-conserved core genes involved in replication (E1 and E2) and packaging (L1 and L2) with greater diversity in the remaining genes $(E 6, E 7, E 5$, and $E 4)$, which have roles in driving cell cycle entry, immune evasion, and virus release [8]. Although the expression of these viral genes and their roles have been investigated extensively in high-risk HPVs [6,8], they remain unclear in LP with low-risk HPV infection, such as the cells that express these genes and the dynamic variations of HPV viral load in primary tumors and recurrent tumors after treatment [9].

$E 4$ is located centrally within the E2 gene (Figure 1), and the primary E4 gene product $\left(E 1^{\wedge} E 4\right)$ is translated from a spliced mRNA [10]. Although several minor E4 transcripts have been reported, it is the product of the abundant $E 1^{\wedge} E 4 \mathrm{mRNA}$ that has been most extensively analyzed [11]. E4 protein encoded by HPV-16 appears to have the ability to bind to keratin and to reorganize the cellular keratin network, suggesting a role in virus release and transmission [10]. HPV-6 and -11 contain a second open reading frame downstream of $E 5 a$, which is called $E 5 b$. E5b shows no sequence similarity to other E5 proteins. Although HPV-16 E5 can activate the epidermal growth factor receptor, inhibit the expression of the p21 tumor suppressor gene [12,13], and has a role in immunoevasion [14], the biological functions of $E 5 a$ and $E 5 b$ in low-risk HPVs are not understood fully.

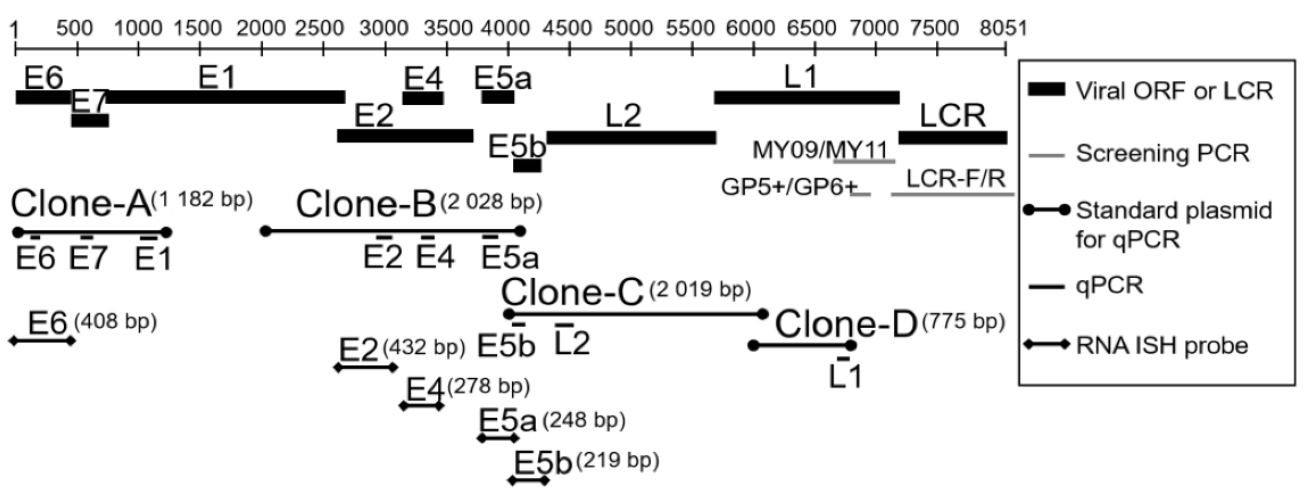

Figure 1. Schema of human papillomavirus-6 (HPV-6) genes and information of plasmid clones and RNA in situ hybridization probes used in this study.

LP caused by HPV-6 and -11 infection is a chronic and recurrent disease that significantly lowers patients' quality of life and may lead to life-threatening conditions. Furthermore, effective clinical treatments have not been established. Therefore, it is vitally important to characterize the underlying pathogenic mechanisms. However, the detailed molecular mechanisms of HPV-driven tumorigenesis are mostly unknown. In the present study, we established a real-time polymerase chain reaction (PCR) assay to measure the absolute levels of E6,E7,E1,E2,E4,E5a,E5b, L2, and $L 1$ mRNAs, an mRNA in situ hybridization (ISH) method for $E 6, E 2, E 4, E 5 a$, and $E 5 b$, and created an anti-E4 monoclonal antibody for immunohistochemical localization of E4 in LP. 


\section{Materials and Methods}

\subsection{Subjects}

The subjects consisted of 16 patients with LP aged from 4 to 67 years at the first visit to our hospital between 2010 and 2018. Tumor specimens were frozen immediately in liquid nitrogen at biopsy or surgical excision between 2010 and 2018 and stored at $-80{ }^{\circ} \mathrm{C}$ until analysis.

The HPV subtypes were determined as described previously [15]. Of the 16 patients, $13(81.3 \%)$ had HPV-6 and $3(18.7 \%)$ had HPV-11. Since the major HPV subtype was HPV-6, the present study focused on HPV-6-infected LP and analyzed the viral DNA load, mRNA expression of viral genes, and cellular localization of viral genes and proteins by PCR, real-time PCR, DNA- and RNA-ISH (in situ hybridization), and immunohistochemistry using self-made probes and antibodies. Since sufficient fresh-frozen samples were obtained from 10 of 13 LP patients, mRNA expression was evaluated using these samples (Table 1). Several fresh-frozen samples at sites of recurrence were obtained from 2 of 13 patients with HPV-6-positive LP (cases 9 and 10).

Table 1. Clinical profiles of 13 patients with HPV-6-infected laryngeal papilloma (LP).

\begin{tabular}{|c|c|c|c|c|c|c|c|}
\hline Case & Age (Years) & Sex & Surgery & No. of Tumors & Subsite & Derkay Score & HPV Subtype \\
\hline 1 & 27 & M & $3 \mathrm{rd}$ & Multiple & B, TVC; B, FVC & 15 & HPV-6a \\
\hline 2 & 43 & $\mathrm{M}$ & $1 \mathrm{st}$ & multiple & B, TVC; L, FVC & 13 & HPV-6b \\
\hline 3 & 34 & M & 2nd & multiple & B, FVC & 6 & HPV-6b \\
\hline 4 & 41 & $\mathrm{M}$ & $1 \mathrm{st}$ & multiple & B, TVC & 4 & HPV-6vc \\
\hline 5 & 41 & $\mathrm{M}$ & $1 \mathrm{st}$ & single & $\mathrm{R}, \mathrm{TVC}$ & 2 & HPV-6ve \\
\hline 6 & 17 & $\mathrm{~F}$ & 1 st & multiple & B, TVC & 6 & HPV-6vc \\
\hline 7 & 28 & M & $1 \mathrm{st}$ & multiple & B, TVC & 2 & HPV6-a \\
\hline 8 & 4 & F & $1 \mathrm{st}$ & multiple & $\mathrm{B}, \mathrm{TVC}$ & 6 & HPV-6vc \\
\hline \multirow{2}{*}{9} & 59 & \multirow{2}{*}{$\mathrm{M}$} & $1 \mathrm{st}$ & multiple & B, TVC & 6 & \multirow{2}{*}{ HPV6-vc } \\
\hline & 61 & & 4 th & multiple & B, TVC & 3 & \\
\hline \multirow{10}{*}{10} & 67 & \multirow{10}{*}{$\mathrm{M}$} & $1 \mathrm{st}$ & multiple & B, TVC & 2 & \multirow{10}{*}{ HPV6-vc } \\
\hline & 68 & & 2 nd & multiple & B, TVC & 14 & \\
\hline & 69 & & 3rd & multiple & $\mathrm{L}, \mathrm{TVC}$ & 17 & \\
\hline & 69 & & 4th & multiple & B, TVC & 12 & \\
\hline & 71 & & 5 th & multiple & B, TVC & 6 & \\
\hline & 72 & & 6th & multiple & B, TVC & 11 & \\
\hline & 73 & & 7th & multiple & B, TVC & 14 & \\
\hline & 73 & & 8th & multiple & B, TVC & 15 & \\
\hline & 73 & & 9th & multiple & B, TVC & 12 & \\
\hline & 74 & & 10th & multiple & B, TVC & 15 & \\
\hline 11 & 45 & $\mathrm{M}$ & $1 \mathrm{st}$ & multiple & B, TVC & 6 & HPV-6 \\
\hline 12 & 44 & M & $1 s t$ & single & $\mathrm{R}, \mathrm{TVC}$ & 3 & HPV-6a \\
\hline 13 & 44 & $\mathrm{M}$ & $1 \mathrm{st}$ & single & L, TVC & 2 & HPV-6 \\
\hline
\end{tabular}

B, bilateral; F, female; FVC, false vocal cord; L, left; M, male; R, right; TVC, true vocal cord.

\subsection{Detection of Human Papillomavirus (HPV) DNA and Quantitative Polymerase Chain} Reaction (PCR) Analysis of HPV-6 Viral Load

2.2.1. Extraction of Genomic DNA from Laryngeal Papilloma (LP) and PCR Conditions

DNA was extracted from fresh-frozen samples using a Gentra Puregene Tissue Kit (QIAGEN, Gaithersburg, MD, USA) [15]. The presence and integrity of DNA in all samples were investigated by PCR amplification of the $\beta$-globin gene using primers PC04 and GH20. The primers used in the present study are shown in Table S1 in the 
Supplementary Materials. The amplification efficiency of target genes is shown in Table S2 in the Supplementary Materials.

Negative (water) and positive (DNA from an HPV-16-positive CaSki cell line) controls were included in each amplification series. To determine the HPV subtypes in the samples, we used the degenerate consensus primer sets GP5+/GP6+ and MY09/MY11 [16], which were designed to amplify the L1 region. When no PCR amplification occurred with the GP5+/GP6+ or MY09/MY11 primers, 10-fold diluted first-round PCR products were used as template DNA for nested PCR using the GP5+/GP6+ primer pair. PCR products of the expected size (GP5+/GP6+, $150 \mathrm{bp}$; MY09/MY11, $450 \mathrm{bp}$ ) were purified and directly sequenced with an ABI PRISM 3130xl Genetic Analyzer (Applied Biosystems; Thermo Fisher Scientific, Inc., Waltham, MA, USA). The sequences were aligned and compared with the $L 1$ gene of known HPV subtypes in GenBank using blastn: https: / /blast.ncbi.nlm.nih. gov / Blast.cgi?PROGRAM=blastn\&PAGE_TYPE=BlastSearch\&LINK_LOC=blasthome (accessed on 13 February 2021).

\subsubsection{Partial Cloning of the HPV-6-LCR Region and Identification of HPV-6 Subtypes}

To identify the HPV-6 subtype, we designed LCR-degenerate primers in the conserved region from L1 to E6 of HPV-6a (GenBank accession no. L41216), HPV-6b (X00203), and HPV-6vc (JN252316). For amplification, PCR was performed with LCR-F and LCR-R primers $(0.24 \mu \mathrm{M}$ each, Table S1 in the Supplementary Materials) in a mixture $(12.5 \mu \mathrm{L})$ containing $6.3 \mu \mathrm{L}$ GoTaq $^{\circledR}$ Green Master Mix (Promega, Madison, WI, USA) and $10 \mathrm{ng}$ genomic DNA. The PCR profile was as follows: denaturation at $95^{\circ} \mathrm{C}$ for $15 \mathrm{~min}$, followed by 45 cycles at $95^{\circ} \mathrm{C}$ for $15 \mathrm{~s}, 60^{\circ} \mathrm{C}$ for $30 \mathrm{~s}$, and $72{ }^{\circ} \mathrm{C}$ for $2 \mathrm{~min}$, and a final extension at $72{ }^{\circ} \mathrm{C}$ for $5 \mathrm{~min}$. PCR fragments of the expected size were purified by the Wizard SV Gel and PCR Clean-Up System (Promega, Madison, WI, USA). The purified PCR products were cloned into the PGEM-T Easy vector (Promega, Madison, WI, USA) and sequenced with an ABI PRISM 3130xl Genetic Analyzer (Applied Biosystems, Foster City, CA, USA).

The obtained nucleotide sequences of the LCR region were compared with HPV-6a, HPV-6b, and HPV-6vc by the GENETYX sequence analysis software package (Software Development Co., Ltd., Tokyo, Japan). Multiple alignments for phylogenetic analysis were performed by the GENETYX sequence analysis software package. A phylogenetic tree was constructed by the unweighted pair group method with arithmetic mean, using the GENETYX sequence analysis software package. The LCR region sequence of HPV-11 served as an outgroup for the phylogenetic tree.

\subsubsection{Quantitative PCR Analysis of HPV-6 Viral Load in LP}

To evaluate the viral load of HPV-6-infected LP, quantitative PCR was performed as described previously [17]. HPV-6 E6 DNA copy number in genomic DNA was determined with the ABI Prism 7300 Sequence Detection System (Applied Biosystems, Foster City, CA, USA) or CFX96 Touch ${ }^{\text {TM }}$ Real-Time PCR Detection System (Bio-Rad, Hercules, CA, USA). Briefly, serially diluted HPV-6 E6 plasmid (p1478 HPV-6 E6; Addgene, Cambridge, MA, USA) was used as a standard $\left(1.0 \times 10^{1}-1.0 \times 10^{7}\right.$ copies $\left./ 2 \mu \mathrm{L}\right)$ to establish a standard curve. p1478 HPV-6 E6 was a gift from Peter Howley (Addgene plasmid \#10872; http: //n2t.net/addgene:10872; accessed on 13 February 2021). The genomic DNA samples from the patients were diluted to $30 \mathrm{ng} / 2 \mu \mathrm{L}$ and used for measurement. The PCR reaction mixture $(10 \mu \mathrm{L})$ contained $0.2 \mu \mathrm{M}$ primers, $0.15 \mu \mathrm{M}$ TaqMan probe (Table S1 in the Supplementary Materials), $5 \mu \mathrm{L}$ TaqMan Universal Master Mix II with Uracil-DNA Glycosylase (UNG; Applied Biosystems, Carlsbad, CA, USA), and $2 \mu \mathrm{L}$ template DNA. The PCR profile was as follows: $50^{\circ} \mathrm{C}$ for $2 \mathrm{~min}$ and $95^{\circ} \mathrm{C}$ for $10 \mathrm{~min}$, followed by 40 cycles at $95^{\circ} \mathrm{C}$ for $15 \mathrm{~s}$ and $60^{\circ} \mathrm{C}$ for $1 \mathrm{~min}$. To quantify sample DNA amounts, an external standard curve was created using known serial dilutions $(0.3,3,30$, and $300 \mathrm{ng})$ of human placental genomic DNA (Sigma-Aldrich, Merck KGaA, Darmstadt, Germany), and $\beta$-globin was amplified as described previously [17]. Viral load was defined by E6 copy number/ng cellular DNA. 


\subsection{Measurement of Viral mRNA Expression in HPV-6-infected LP by Quantitative Real-Time PCR}

According to the manufacturer's instructions, total RNA was extracted from freshfrozen LP samples with RNAiso Plus (Takara, Otsu, Japan). Total RNA (500 ng) from each sample was reverse-transcribed using the PrimeScript ${ }^{R}$ RT Reagent with gDNA Eraser (Takara, Otsu, Japan). To establish real-time PCR assays to measure the absolute levels of $E 7, E 1, E 2, E 4, E 5 a, E 5 b, L 2$, and $L 1$ mRNAs, we cloned 4 regions of HPV-6 gene fragments using genomic DNA from patient 3 (clones A, B, C, and D in Figure 1). Clone A was amplified from the anterior region of the $E 6$ gene to the anterior one-third of the $E 1$ gene (nt5-nt1186, 1182 bp) using primer pairs (F1 and R1 in Table S1 in the Supplementary Materials). Clone $B$ was amplified from the posterior one-third of the $E 1$ gene to the anterior one-half of the $E 5 b$ gene (nt2117-nt4144, $2028 \mathrm{bp}$ ) using primer pairs ( $F 2$ and $R 2$ in Table S1 in the Supplementary Materials). Clone C was amplified from the anterior region of the $E 5 b$ gene to the anterior one-third of the L1 gene (nt4005-nt6023, $2019 \mathrm{bp}$ ) using primer pairs (F3 and R3 in Table S1 in the Supplementary Materials). Clone D was amplified from the anterior one-third of the L1 gene to the posterior one-third of the $L 1$ gene (nt6001-nt6775, $775 \mathrm{bp}$ ) using primer pairs ( $F 4$ and $R 4$ in Table S1 in the Supplementary Materials). The PCR reaction mixture $(12.5 \mu \mathrm{L})$ contained $1 \mu \mathrm{L}$ genomic DNA from patient-3 $(30 \mathrm{ng} / \mu \mathrm{L}), 0.24 \mu \mathrm{M}$ forward and reverse primers, and $6.3 \mu \mathrm{L}$ GoTaq ${ }^{\circledR}$ Green Master Mix (Promega, Madison, WI, USA). The PCR conditions comprised: $95^{\circ} \mathrm{C}$ for $15 \mathrm{~min}$, followed by 40 cycles at $95^{\circ} \mathrm{C}$ for $30 \mathrm{~s}, 55^{\circ} \mathrm{C}$ for $30 \mathrm{~s}$, and $72{ }^{\circ} \mathrm{C}$ for $3 \mathrm{~min}$, and finally $72{ }^{\circ} \mathrm{C}$ for $7 \mathrm{~min}$. The PCR fragments of the expected size were purified using the Wizard SV Gel and PCR Clean-Up System (Promega, Madison, WI, USA). The purified PCR products were cloned into the pGEM-T Easy vector (Promega, Madison, WI, USA) and sequenced using an ABI PRISM 3130xl Genetic Analyzer. The sequences obtained were analyzed as mentioned above. The plasmids (clones A, B, C, and D) were serially diluted to $2.0 \times 10^{1}-2.0 \times 10^{7}$ copies $/ 2 \mu \mathrm{L}$ as standards for $E 7, E 1, E 2, E 4, E 5 a, E 5 b, L 2$, and L1 genes to establish a standard curve in real-time PCR. Real-time PCR was performed with the ABI Prism 7300 Sequence Detection System (Applied Biosystems, Foster City, CA, USA) or CFX96 Touch ${ }^{\mathrm{TM}}$ Real-Time PCR Detection System (Bio-Rad, Hercules, CA, USA). The PCR reaction mixture $(10 \mu \mathrm{L})$ contained $0.2 \mu \mathrm{M}$ primers, $5 \mu \mathrm{L}$ SYBR Premix Ex Taq $^{\mathrm{TM}}$ II (Tli RNaseH plus; Takara, Otsu, Japan), and $2 \mu \mathrm{L}$ standard plasmid DNA $\left(2.0 \times 10^{1}-2.0 \times 10^{7}\right.$ copies $)$ or cDNA. The PCR profile was as follows: $95{ }^{\circ} \mathrm{C}$ for $30 \mathrm{~s}$ followed by 40 cycles at $95^{\circ} \mathrm{C}$ for $5 \mathrm{~s}$ and $60^{\circ} \mathrm{C}$ for $30 \mathrm{~s}$. Specific amplification of each cDNA was verified by melting curve analysis and gel electrophoresis of the products. The real-time PCR assay for E6 mRNA was performed with the same E6 primers and TaqMan probe as well as the same protocol described above. We also measured $\beta$-actin mRNA as the internal reference. The plasmid pCAG-mGFP-Actin (a gift from Ryohei Yasuda), carrying the entire coding region of $\beta$-actin (Addgene plasmid \#21948; Addgene, Cambridge, MA, USA), was serially diluted to $1.0 \times 10^{1}-1.0 \times 10^{7}$ copies $/ 2 \mu \mathrm{L}$ to establish a standard curve. The PCR reaction mixture $(10 \mu \mathrm{L})$ contained $0.2 \mu \mathrm{M}$ primers, $0.15 \mu \mathrm{M}$ TaqMan probe (Table S1 in the Supplementary Materials), $5 \mu \mathrm{L}$ TaqMan Universal Master Mix II with UNG, and $2 \mu \mathrm{L}$ template DNA. The PCR profile was as follows: $50^{\circ} \mathrm{C}$ for $2 \mathrm{~min}$ and $95{ }^{\circ} \mathrm{C}$ for $10 \mathrm{~min}$, followed by 40 cycles at $95^{\circ} \mathrm{C}$ for $15 \mathrm{~s}$ and $60^{\circ} \mathrm{C}$ for $1 \mathrm{~min}$. $\beta$-Actin mRNA levels were used to normalize all viral mRNA levels.

\subsection{In Situ Hybridization (ISH) with HPV DNA Probes}

Biotinyl tyramide-based ISH was performed using the HPV Types 6/11 Biotinylated DNA Probe (Y1411; Dako, Agilent Technologies, Inc., Santa Clara, CA, USA) and the GenPoint tyramide signal amplification system for biotinylated probes according to the manufacturer's protocol (Dako, Agilent Technologies, Inc., Santa Clara, CA, USA). The biotinylated DNA probe has been found to react with HPV-6 and -11 in formalin-fixed paraffin-embedded (FFPE) sections by ISH. Serial $4-\mu \mathrm{m}$-thick sections of FFPE samples were deparaffinized in xylene and rehydrated using a graded alcohol series. Target HPV DNA retrieval was performed in $10 \mathrm{mM}$ sodium citrate (at pH 6.0) at $95^{\circ} \mathrm{C}$ for $40 \mathrm{~min}$ followed 
by a 20-min cooldown period. The slides were digested with proteinase $\mathrm{K}(10,000$ times dilution with Tris-buffered saline; Dako, Agilent Technologies, Santa Clara, CA, USA) for $10 \mathrm{~min}$ at room temperature. Endogenous peroxidases were blocked with $0.3 \% \mathrm{H}_{2} \mathrm{O}_{2}$ in methanol for $20 \mathrm{~min}$. A drop of the HPV probe was added to the section, and a coverslip was applied. The probe and target DNA were denatured by incubating the slides at $92{ }^{\circ} \mathrm{C}$ for $5 \mathrm{~min}$. After denaturation, the slides were transferred to a humidified chamber for hybridization at $37^{\circ} \mathrm{C}$ for $16 \mathrm{~h}$. After hybridization, the coverslips were removed, and the slides were bathed in Tris-buffered saline containing 0.05\% Tween 20 (TBST). The coverslips were washed using GenPoint Detection system stringent wash solution (Dako, Agilent Technologies, Santa Clara, CA, USA) at $48^{\circ} \mathrm{C}$ for $30 \mathrm{~min}$, following by rinsing in TBST. Detection of the hybridized probe was performed using the GenPoint Detection system with primary streptavidin-horseradish peroxidase (HRP), biotinyl tyramide, secondary streptavidin-HRP, and 3-3'-diaminobenzidine (Dako, Agilent Technologies, Santa Clara, CA, USA). The slides were counterstained with hematoxylin.

\subsection{RNA-ISH with HPV-6 E6, E2, E4, E5a, and E5b Digoxigenin RNA Probes}

For RNA-ISH, the E6,E2, E4,E5a, and E5b genes of HPV-6 were amplified by the following PCR method. The primer sets are shown in Table S1 in the Supplementary Materials. The PCR reaction mixture $(12.5 \mu \mathrm{L})$ contained $1 \mu \mathrm{L}$ template plasmid (clone A plasmid for E6; clone B plasmid for E2, E4, and E5a; clone C plasmid for E5b), $0.24 \mu \mathrm{M}$ forward and reverse primers, and $6.3 \mu \mathrm{L}$ GoTaq ${ }^{\circledR}$ Green Master Mix (Promega, Madison, WI, USA). The PCR conditions comprised: $95{ }^{\circ} \mathrm{C}$ for $5 \mathrm{~min}$, followed by 35 cycles at $95^{\circ} \mathrm{C}$ for $30 \mathrm{~s}, 6{ }^{\circ} \mathrm{C}$ for $30 \mathrm{~s}$, and $72{ }^{\circ} \mathrm{C}$ for $1 \mathrm{~min}$, and finally $72{ }^{\circ} \mathrm{C}$ for $5 \mathrm{~min}$. The PCR products were subcloned into the pGEM-T Easy vector (Promega, Madison, WI, USA) as described above. Anti-sense RNA probes were transcribed from linearized plasmids using a digoxigenin (DIG)-labeling mix (Roche Diagnostics, Mannheim, Germany) and SP6 or T7 RNA polymerase (Takara, Otsu, Japan), and digested with DNase I (Takara, Otsu, Japan). A total of $1 \mu \mathrm{g}$ of the linearized plasmid DNA was used in a $20-\mu \mathrm{L}$ reaction for DIG-RNA labeling. The probes were stored at $-80^{\circ} \mathrm{C}$ until use.

LP FFPE samples were sectioned at $4 \mu \mathrm{m}$ and mounted onto adhesive glass slides (Platinum Pro ${ }^{\circledR}$; Matsunami Glass, Osaka, Japan). The sections were deparaffinized in xylene and rehydrated in a graded alcohol series, followed by incubation in ultra-pure water for $5 \mathrm{~min}$. After washing with phosphate-buffered saline (PBS) with $0.1 \%$ Tween 20 (PBST), the sections were incubated in PBST including proteinase $\mathrm{K}$ (final concentration $0.01 \mathrm{mg} / \mathrm{mL}$; Agilent Technologies Japan, Tokyo, Japan) for $5 \mathrm{~min}$ at $37^{\circ} \mathrm{C}$, and fixed in $4 \%$ paraformaldehyde (Nacalai Tesque, Kyoto, Japan) for $15 \mathrm{~min}$ at room temperature. After washing with PBST, pre-hybridization was performed in a hybridization buffer containing $50 \%$ deionized formamide, $5 \times$ saline-sodium citrate $(S S C ; 1 \times$ SSC $=0.15 \mathrm{M}$ $\mathrm{NaCl}$ and $0.015 \mathrm{M}$ sodium citrate, $\mathrm{pH} 7.0$ ), $50 \mu \mathrm{g} / \mathrm{mL}$ heparin (Nacalai Tesque, Kyoto, Japan), $100 \mu \mathrm{g} / \mathrm{mL}$ Escherichia coli tRNA (Roche Diagnostics, Mannheim, Germany), 1\% sodium dodecyl sulfate (SDS), and $0.1 \%$ Tween 20 at $60^{\circ} \mathrm{C}$ for $1 \mathrm{~h}$, and hybridization was performed with DIG-labeled RNA probes $\left(1 \mu \mathrm{g} / \mathrm{mL}\right.$ in hybridization solution) at $60{ }^{\circ} \mathrm{C}$ overnight in a humidified chamber. After hybridization, the sections were washed as follows: for $5 \mathrm{~min}$ in $50 \%$ formamide in $2 \times$ SSC with $0.1 \%$ Tween 20 at $60{ }^{\circ} \mathrm{C} ; 5 \mathrm{~min}$ in $2 \times \mathrm{SSC}$ at $60{ }^{\circ} \mathrm{C}$; and $5 \mathrm{~min}$ in $0.2 \% \mathrm{SSC}$ at room temperature. The sections were washed 3 times with PBST at room temperature, incubated with blocking buffer $(0.5 \%$ blocking reagent in PBST, Roche Diagnostics, Mannheim, Germany) for $15 \mathrm{~min}$, and incubated with 1:3000 anti-Digoxigenin-AP (alkaline phosphatase), Fab fragments (Roche Diagnostics, Mannheim, Germany) in the blocking buffer at $4{ }^{\circ} \mathrm{C}$ overnight. The sections were rinsed 3 times with PBST and washed with reaction buffer $(100 \mathrm{mM}$ Tris- $\mathrm{HCl}, 100 \mathrm{mM} \mathrm{NaCl}$, $50 \mathrm{mM} \mathrm{MgCl}_{2}, \mathrm{pH}$ 8.0). Section detection was carried out using a nitroblue tetrazolium/5bromo-4-chloro-3-indolyl phosphate solution (Roche Diagnostics, Mannheim, Germany) in the reaction buffer. The sections were washed 3 times with PBST and counterstained with Vector ${ }^{\circledR}$ Nuclear Fast Red (Vector Laboratories, Burlingame, CA, USA). 


\subsection{Double Fluorescence RNA-ISH}

Double fluorescence RNA-ISH was performed using the TSA ${ }^{\mathrm{TM}}$ Fluorescein System (PerkinElmer, Waltham, MA, USA) and TSA ${ }^{\mathrm{TM}}$ Cyanine 5 System (PerkinElmer, Waltham, MA, USA). An anti-sense E4 DIG-RNA probe was prepared as described above. Anti-sense $E 5 a$ and $E 5 b$ biotin probes were transcribed from linearized plasmid using Biotin RNA Labeling Mix (Roche Diagnostics, Mannheim, Germany) and SP6 or T7 RNA polymerase, and digested with DNase I as described above. The probes were stored at $-80^{\circ} \mathrm{C}$ until use.

The process from sectioning to hybridization was the same as described above. Hybridization was performed with an anti-sense E4 DIG-labeled RNA probe and anti-sense E5a biotin-labeled RNA probe (each $1 \mu \mathrm{g} / \mathrm{mL}$ in hybridization solution) or anti-sense $E 4$ DIG-labeled RNA probe and anti-sense $E 5 b$ biotin-labeled RNA probe (each $1 \mu \mathrm{g} / \mathrm{mL}$ in hybridization solution) at $60^{\circ} \mathrm{C}$ overnight in a humidified chamber. After hybridization, the sections were washed as follows: for $5 \mathrm{~min}$ in $50 \%$ formamide in $2 \times$ SSC with $0.1 \%$ tween at $60{ }^{\circ} \mathrm{C} ; 5 \mathrm{~min}$ in $2 \times \mathrm{SSC}$ at $60^{\circ} \mathrm{C}$; and $5 \mathrm{~min}$ in $0.2 \% \mathrm{SSC}$ at room temperature. The sections were washed 3 times with PBST at room temperature, incubated with blocking buffer $(0.5 \%$ blocking reagent in PBST) for $15 \mathrm{~min}$, and incubated with 1:100 anti-Digoxigenin-POD (horse-radish peroxidase), Fab fragments (Sigma-Aldrich, Merck KGaA, Darmstadt, Germany) in the blocking buffer at $4{ }^{\circ} \mathrm{C}$ overnight. The sections were rinsed 3 times with PBST and washed with Tris-NaCl-Tween buffer (TNT buffer: $100 \mathrm{mM}$ Tris- $\mathrm{HCl}, 150 \mathrm{mM} \mathrm{NaCl}$, $0.1 \%$ Tween 20, $\mathrm{pH} 7.5$ ). The fluorescein tyramide reagent from the $\mathrm{TSA}^{\mathrm{TM}}$ Fluorescein System (PerkinElmer, Waltham, MA, USA) was diluted at 1:50 with the amplification diluent and mounted onto adhesive glass slides at room temperature for $10 \mathrm{~min}$. Then, the sections were washed 3 times with PBST at room temperature. Endogenous peroxidases were blocked with $3 \% \mathrm{H}_{2} \mathrm{O}_{2}$ in PBST at room temperature for $1 \mathrm{~h}$. The sections were rinsed 3 times with PBST and incubated with Tris-NaCl-blocking buffer (TNB buffer: $0.5 \%$ blocking reagent in TNT buffer, TSA ${ }^{\mathrm{TM}}$ Fluorescein System Kit). Streptavidin-HRP was diluted at 1:250 with TNB buffer (TSA ${ }^{\mathrm{TM}}$ Cyanine 5 System; PerkinElmer, Waltham, MA, USA) and mounted on the slides for $30 \mathrm{~min}$. The slides were washed 3 times with TNT buffer. The cyanine 5 tyramide reagent was applied to the slides for $10 \mathrm{~min}$. Then, the slides were washed 3 times with TNT buffer and washed twice with PBS. Nuclei were counterstained with $10 \mu \mathrm{g} / \mathrm{mL}$ Hoechst 33,342 (Thermo Fisher Scientific, Tokyo, Japan) in PBST for $10 \mathrm{~min}$. The slides were washed 3 times with PBS. Fluorescence was detected with an Axio Imager M2 microscope (Zeiss Japan, Tokyo, Japan) equipped with Colibri.2 light-emitting diode (LED) illumination and the Apotome.2 system (Zeiss Japan, Tokyo, Japan).

\subsection{Immunohistochemistry for HPV-6 E4}

\subsubsection{Preparation of an Anti-HPV-6 E4 Monoclonal Antibody}

To generate a specific antibody against HPV-6 E1^Е4, an alpaca variable domain of heavy chain of heavy-chain (VHH) antibody library was used as described previously [18]. Then, the alpaca $V H H$ gene was fused with the mouse $I g G F c$ gene. The peptides and antibody were prepared by RePHAGEN Co., Ltd. (Okinawa, Japan).

\subsubsection{Evaluation of Antibody Specificity}

Plasmid Construction. HPV-6 E1^E4 and HPV-11 E1^$E 4$ were cloned into the pcDNA3.1+ vector, with the $3 \times$ FLAG-tag at the N-terminus [19]. Human Chemokine-like factor (CKLF)like MARVEL transmembrane domain-containing 7 (CMTM7) tagged with $3 \times$ FLAG at the $\mathrm{N}$-terminus was also used as described previously [19].

Cell Culture and Transfection. Human embryonic kidney HEK293T cells were cultured in high-glucose Dulbecco's modified Eagle's medium (DMEM) supplemented with 10\% fetal bovine serum (FBS) and penicillin/streptomycin. HEK293T cells $\left(2.0 \times 10^{6}\right.$ cells) were cultured in a $10-\mathrm{cm}$ dish for $24 \mathrm{~h}$. Immediately before transfection, the cells were rinsed and supplemented with fresh culture medium (high-glucose DMEM) without FBS and penicillin/streptomycin. Transfection was performed using HilyMax (Dojindo, Kumamoto,

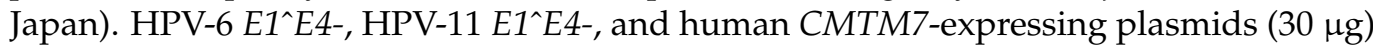


were mixed with $15 \mu \mathrm{L}$ HilyMax and $900 \mu \mathrm{L}$ high-glucose DMEM and incubated for $15 \mathrm{~min}$. Then, the DNA mixture was added to the cells. After 4-h incubation, high-glucose DMEM including 10\% FBS and penicillin/streptomycin was added to the cells. The cells were cultured for $48 \mathrm{~h}$ after transfection. Non-transfected cells were included in the transfection experiments.

Western Blotting for HPV-6 E4. HEK293T cells expressing HPV-6 E1^E4, HPV-11 E1^E4, or human CMTM7 and non-transfected HEK293T cells were lysed in a buffer containing $62.5 \mathrm{mM}$ Tris- $\mathrm{HCl}$ (pH 6.8), 2\% SDS, and 10\% glycerol. Lysate protein concentration was measured using a DC Protein Assay Kit (Bio-Rad, Hercules, CA, USA). Each protein sample was prepared at $50 \mu \mathrm{g} / 10 \mu \mathrm{L}$ in $62.5 \mathrm{mM}$ Tris- $\mathrm{HCl}(\mathrm{pH}$ 6.8), 2\% SDS, 10\% glycerol, $6 \%$ mercaptoethanol, and $0.01 \%$ bromophenol blue and boiled for $5 \mathrm{~min}$. The samples were electrophoresed in $12.5 \%$ acrylamide SDS-PAGE and transferred to polyvinylidene difluoride membranes. To confirm the expression of HPV-6 E1^E4, HPV-11 E1^Е4, and human CMTM7, FLAG protein was detected with an HRP-conjugated monoclonal antiFLAG M2 antibody (Sigma-Aldrich, Merck KGaA, Darmstadt, Germany) diluted at 1:1000 with Can Get Signal Solution 2 (Toyobo, Osaka, Japan). To evaluate the specificity of the anti-HPV-6 E1^E4 antibody (alpaca VHH fused with mouse IgG1 Fc), the antibody was used as a primary antibody without dilution. A secondary antibody, goat IgG-conjugated with HRP against mouse IgG (H+L) (Bio-Rad, Hercules, CA, USA), was used at a dilution of 1:1000 with Can Get Signal Solution 2 (Toyobo, Osaka, Japan). Bands were visualized using Clarity Western ECL Substrate (Bio-Rad, Hercules, CA, USA) and the ChemiDoc XRS+ System (Bio-Rad, Hercules, CA, USA).

\subsubsection{Immunohistochemistry for HPV-6 E1^E4}

For HPV-6 E1^E4 immunohistochemistry, 4- $\mu$ m-thick sections from FFPE samples were deparaffinized in xylene and hydrated in a graded alcohol series. Epitope retrieval was achieved by heating at $100{ }^{\circ} \mathrm{C}$ for $10 \mathrm{~min}$ in $1 \mathrm{mM}$ Ethylenediaminetetraacetic acid (EDTA) buffer ( $\mathrm{pH}$ 8.0). Endogenous peroxidase activity was quenched by incubating the sections in $0.3 \% \mathrm{H}_{2} \mathrm{O}_{2}$ in methanol for $20 \mathrm{~min}$ at room temperature. According to the manufacturer's protocol, a SAB-PO Kit (Nichirei Bioscience, Tokyo, Japan) was used to detect immunoreactivity to HPV-6 E1^E4. After blocking non-specific reactions by incubation in $10 \%$ goat serum, the tissue slides were incubated with the primary antibody against HPV-6 E4 (alpaca VHH fused with mouse IgG1 Fc) overnight at $4{ }^{\circ} \mathrm{C}$. Subsequently, a biotin-labeled secondary antibody and peroxidase-labeled streptavidin were applied. Immunolabeling was visualized by incubation in 3-3'-diaminobenzidine, and stained slides were counterstained with hematoxylin.

\subsection{Statistical Analysis}

Viral mRNA levels (the proportion of viral mRNA expression as a percentage) were analyzed by the Kruskal-Wallis test, followed by the Dwass-Steel-Critchlow-Fligner multiple comparison test to detect statistically significant differences in the mRNA levels of the 9 viral genes. The correlations among the levels of the 9 viral mRNAs were analyzed by Spearman's rank-order correlation test. The correlations between viral load and viral mRNA levels were analyzed as described above. Statistical significance was set at $p<0.05$. Statistical analyses were performed using NCSS Statistical Software ver.12 (Kaysville, UT, USA).

\subsection{Ethics Approval and Consent to Participate}

This study was approved by the Institutional Review Board of the University of Ryukyus and was carried out in accordance with the 1975 Declaration of Helsinki, as revised in 2008. Informed consent was obtained from all patients before enrollment. 


\section{Results}

\subsection{HPV DNA Distribution, Subtypes, and Viral Load in LP}

The clinicopathological characteristics of 23 specimens obtained from 13 patients with HPV-6-infected LP are summarized in Table 1. The Derkay score [20] ranged from 2 to 17 (Table 1). In 21 specimens, the average viral load (mean \pm standard error of the mean [SEM]) was $4.80 \times 10^{5} \pm 1.86 \times 10^{5}$ copies $/$ ng DNA (median, $2.85 \times 10^{4}$, Table 2). Although there were not sufficient samples to analyze HPV subtype in 2 patients (cases 11 and 13), phylogenetic analysis revealed that patients 1,7 , and 11 were clustered within the HPV-6a subtype (JN252316) and patients 2 and 3 were categorized as the HPV-6b subgroup (X00203), whereas patients 4-6 and 8-10 were closely related to the HPV-6vc subtype (JN252316). There was no significant correlation between the clinical parameters (age, sex, tumor location, Derkay score, and HPV-6 subtype) and viral load/HPV mRNA expression levels.

Table 2. Viral load and mRNA expression.

\begin{tabular}{|c|c|c|c|c|c|c|c|c|c|c|c|}
\hline \multirow{2}{*}{ Case } & \multirow{2}{*}{ Surgery } & \multirow{2}{*}{$\begin{array}{c}\text { Viral Load } \\
\text { (Copies/ng DNA) }\end{array}$} & \multicolumn{9}{|c|}{ HPV mRNA Expression/ $\beta$-actin } \\
\hline & & & $E 6$ & $E 7$ & $E 1$ & $E 2$ & $E 4$ & $E 5 a$ & $E 5 b$ & $L 2$ & $L 1$ \\
\hline 1 & $3 r d$ & $2,268,452$ & 0.110 & 0.179 & 0.026 & 0.185 & 10.675 & 4.766 & 2.900 & 0.010 & 0.012 \\
\hline 2 & $1 \mathrm{st}$ & 649,319 & 0.335 & 0.312 & 0.105 & 0.159 & 4.496 & 24.633 & 8.496 & 0.062 & 0.134 \\
\hline 3 & 2nd & 436 & 0.134 & 0.163 & 0.010 & 0.109 & 0.677 & 2.585 & 1.513 & 0.002 & 0.006 \\
\hline 4 & 1 st & 21,372 & 0.167 & 0.317 & 0.000 & 0.317 & 14.643 & 1.524 & 11.429 & 0.000 & 0.017 \\
\hline 5 & $1 \mathrm{st}$ & 25,347 & 0.425 & 0.153 & 0.010 & 0.213 & 11.474 & 2.241 & 2.309 & 0.001 & 0.002 \\
\hline 6 & $1 s t$ & 4739 & 0.135 & 0.218 & 0.003 & 0.059 & 16.934 & 0.004 & 4.460 & 0.000 & 0.010 \\
\hline 7 & $1 s t$ & 14,170 & 0.032 & 0.100 & 0.006 & 0.099 & 6.175 & 1.068 & 1.035 & 0.000 & 0.001 \\
\hline 8 & $1 s t$ & 36,408 & 0.394 & 0.554 & 0.018 & 0.322 & 11.688 & 0.278 & 6.403 & 0.002 & 0.004 \\
\hline \multirow{2}{*}{9} & $1 s t$ & $2,199,081$ & 0.587 & 0.208 & 0.019 & 0.122 & 18.409 & 1.108 & 4.032 & 0.002 & 0.008 \\
\hline & 4th & $2,918,599$ & 0.542 & 2.799 & 0.693 & 5.824 & $20,828.885$ & 74.591 & 256.091 & 6.180 & 0.775 \\
\hline \multirow{10}{*}{10} & 1st & 166,859 & 0.501 & 1.627 & 0.991 & 2.838 & 149.595 & 16.359 & 32.002 & 0.118 & 0.048 \\
\hline & 2nd & 17,173 & 0.634 & 1.841 & 0.448 & 1.806 & 42.551 & 4.378 & 12.183 & 0.025 & 0.020 \\
\hline & $3 \mathrm{rd}$ & 39,002 & 0.401 & 0.177 & 0.027 & 0.223 & 18.655 & 3.723 & 3.061 & 0.002 & 0.007 \\
\hline & 4th & 28,595 & NA & NA & NA & NA & NA & NA & NA & NA & NA \\
\hline & 5 th & 153,164 & 0.500 & 1.543 & 0.790 & 2.312 & 165.797 & 14.312 & 25.824 & 0.318 & 0.283 \\
\hline & 6th & 9551 & 0.083 & 0.092 & 0.007 & 0.103 & 5.951 & 1.657 & 0.796 & 0.001 & 0.001 \\
\hline & 7th & 645,354 & 0.566 & 1.893 & 0.946 & 2.516 & 231.081 & 26.454 & 51.181 & 0.190 & 0.423 \\
\hline & 8th & 24,404 & 0.849 & 2.830 & 1.132 & 3.716 & 290.630 & 23.532 & 52.166 & 0.373 & 0.477 \\
\hline & 9th & 6078 & 0.745 & 1.858 & 0.298 & 1.524 & 44.088 & 4.409 & 7.366 & 0.027 & 0.011 \\
\hline & 10th & 838,013 & 0.406 & 0.960 & 0.269 & 0.947 & 33.520 & 3.924 & 6.529 & 0.040 & 0.009 \\
\hline 11 & $1 \mathrm{st}$ & NA & NA & NA & NA & NA & NA & NA & NA & NA & NA \\
\hline 12 & $1 s t$ & 19,850 & NA & NA & NA & NA & NA & NA & NA & NA & NA \\
\hline 13 & $1 s t$ & NA & NA & NA & NA & NA & NA & NA & NA & NA & NA \\
\hline
\end{tabular}

NA, not available.

The results of HPV DNA-ISH are shown in Table 3. HPV DNA-ISH generated positive signals in the nucleus and cytoplasm of the infected cells, although the intracellular distribution of the positive reaction pattern was different among the cases. Although the positive signals were distributed throughout LP (Figure 2a,b), there were more prominent reactions in the middle and upper cell layers (Figure 2a). 
Table 3. Summary of HPV DNA-ISH, mRNA-ISH, and E4 immunohistochemistry results.

\begin{tabular}{|c|c|c|c|c|c|c|c|c|c|c|c|c|c|c|c|c|c|c|c|c|c|}
\hline \multirow{3}{*}{ Case } & \multirow{2}{*}{\multicolumn{3}{|c|}{ DNA-ISH }} & \multicolumn{15}{|c|}{ HPV RNA-ISH } & \multirow{2}{*}{\multicolumn{3}{|c|}{ E4-IHC }} \\
\hline & & & & \multicolumn{3}{|c|}{$E 6$} & \multicolumn{3}{|c|}{$E 2$} & \multicolumn{3}{|c|}{$E 4$} & \multicolumn{3}{|c|}{$E 5 a$} & \multicolumn{3}{|c|}{$E 5 b$} & & & \\
\hline & $\mathbf{L}$ & $\mathbf{M}$ & $\mathbf{U}$ & $\mathbf{L}$ & $\mathbf{M}$ & $\mathbf{U}$ & $\mathbf{L}$ & $\mathbf{M}$ & $\mathbf{U}$ & L & $\mathbf{M}$ & $\mathbf{U}$ & $\mathbf{L}$ & $\mathbf{M}$ & $\mathbf{U}$ & L & $\mathbf{M}$ & $\mathbf{U}$ & L & $\mathbf{M}$ & $\mathbf{U}$ \\
\hline $1^{*}$ & - & $1+$ & $1+$ & NA & NA & NA & NA & NA & NA & NA & NA & NA & NA & NA & NA & NA & NA & NA & NA & NA & NA \\
\hline 2 & $1+$ & $1+$ & $3+$ & - & - & - & - & - & - & - & - & $1+$ & - & $2+$ & $3+$ & - & - & - & - & $1+$ & $2+$ \\
\hline 3 & $3+$ & $3+$ & $3+$ & - & - & $1+$ & - & $1+$ & - & - & $1+$ & $1+$ & - & $1+$ & $2+$ & - & $1+$ & $2+$ & - & - & $1+$ \\
\hline 4 & $3+$ & $3+$ & $3+$ & - & - & - & - & - & $1+$ & - & - & $1+$ & - & - & - & - & - & - & - & $1+$ & $1+$ \\
\hline 5 & $3+$ & $3+$ & $3+$ & - & - & - & - & - & - & - & - & - & - & - & - & - & - & - & - & $1+$ & $1+$ \\
\hline 6 & - & $2+$ & $2+$ & - & - & - & - & - & $1+$ & - & - & $2+$ & - & - & $1+$ & - & - & - & - & $2+$ & $2+$ \\
\hline 7 & $2+$ & $2+$ & $2+$ & - & - & - & - & - & - & - & - & $2+$ & - & - & - & - & - & - & - & $1+$ & $2+$ \\
\hline 8 & $1+$ & $3+$ & $2+$ & - & - & - & - & - & - & - & $1+$ & $1+$ & - & - & $1+$ & - & - & - & - & $1+$ & $1+$ \\
\hline 9 & - & $3+$ & $3+$ & - & - & $1+$ & - & - & $1+$ & - & $2+$ & $3+$ & - & $1+$ & $2+$ & - & - & $1+$ & - & $2+$ & $3+$ \\
\hline 10 & - & $3+$ & $3+$ & - & - & $1+$ & - & - & - & - & $1+$ & $2+$ & - & $1+$ & $2+$ & - & $1+$ & $2+$ & - & $2+$ & $3+$ \\
\hline 11 & $1+$ & $2+$ & $3+$ & - & $2+$ & $2+$ & $2+$ & $3+$ & $2+$ & - & $2+$ & $3+$ & - & $1+$ & $1+$ & - & $2+$ & $3+$ & - & $2+$ & $3+$ \\
\hline 12 & $1+$ & $1+$ & $3+$ & - & - & - & - & - & $1+$ & - & - & $2+$ & - & $2+$ & $3+$ & - & - & $1+$ & - & $1+$ & $2+$ \\
\hline 13 & $2+$ & $3+$ & $3+$ & - & $1+$ & $2+$ & - & - & - & - & $1+$ & $2+$ & - & $1+$ & $1+$ & - & $1+$ & $1+$ & - & $1+$ & $2+$ \\
\hline
\end{tabular}

ISH, in situ hybridization; IHC, immunohistochemistry; L, lower layer including the basal cell layer (lower third of the epithelium); M, middle layer; $U$, upper cell layer (upper third of the epithelium).-, negative expression; $1+$, expression in less than $20 \%$ of cells; $2+$, expression in $20-50 \%$ of cells; $3+$, expression in more than $50 \%$ of cells. ${ }^{*}$ The formalin-fixed paraffin-embedded (FFPE) sample of case 1 was not sufficient for evaluating RNA-ISH and E4-IHC.

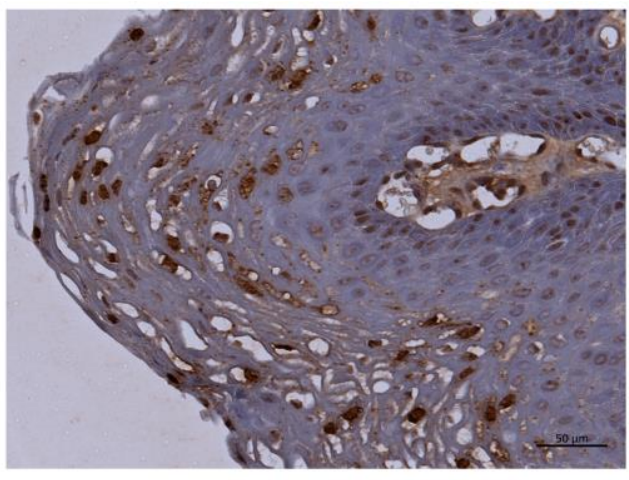

(a)

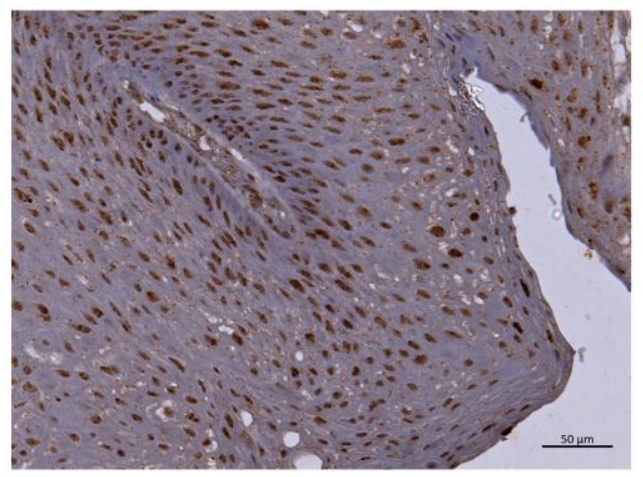

(b)

Figure 2. HPV-6-positive cells in LP by DNA-ISH. (a) The basal cells and middle to upper third layers of LP showed a positive reaction. Bar $=50 \mu \mathrm{m}$. (b) The positive reaction was observed in all LP layers. Bar $=50 \mu \mathrm{m}$.

\subsection{Expression of $H P V-6 m R N A$ s in $L P$}

\subsubsection{Expression Levels of the 9 Viral mRNAs}

The expression levels of the 9 viral mRNAs were determined in 19 tissues from 10 patients (Table 2). E4 mRNA expression (mean \pm SEM) was the highest among these 9 genes $(E 4,1152.94 \pm 1012.18)$ and was followed by $E 5 b$ and $E 5 a$ mRNA levels (E5b, $25.78 \pm 12.32 ; E 5 a, 11.13 \pm 3.67)$. $E 4 \mathrm{mRNA}$ expression was the highest among the 9 viral genes in 8 of 10 patients, while $E 5 a$ and $E 5 b$ mRNA levels were higher than $E 4$ mRNA expression in patients 2 and 3 (Figure 3a). Meanwhile, the mRNA levels of E6, E7, E1,E2, $L 2$, and $L 1$ were much lower than those of $E 4, E 5 b$, and $E 5 a(E 6,0.40 \pm 0.05 ; E 7,0.94 \pm 0.20$; $E 1,0.32 \pm 0.09 ; E 2,1.23 \pm 0.34 ; L 2,0.39 \pm 0.30 ; L 1,0.12 \pm 0.05)$. When the total expression of the 9 viral mRNAs was set to $100 \%$, the percentage of $E 4, E 5 a$, and $E 5 b$ expression was $96 \%(E 4,65.12 \pm 4.68 \% ; E 5 b, 17.23 \pm 1.98 \% ; E 5 a, 13.76 \pm 3.68 \%$ shown in Figure $3 b)$, while 
that of the other 6 genes was only $4 \%(E 6,1.00 \pm 0.19 \% ; E 7,1.34 \pm 0.21 \% ; E 1,0.23 \pm 0.05 \%$;

$E 2,1.22 \pm 0.17 \% ; L 2,0.05 \pm 0.01 \% ; L 1,0.06 \pm 0.02 \%)$.

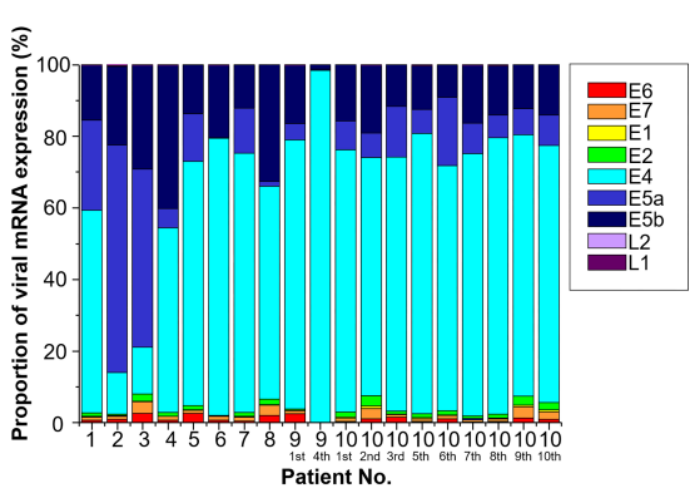

(a)

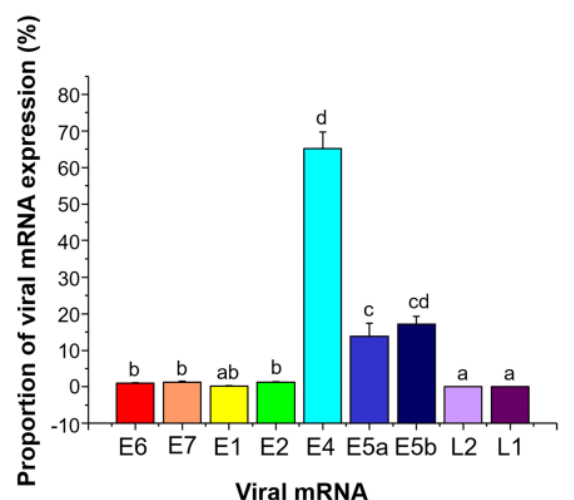

(b)

Figure 3. HPV-6 mRNA expression in individual cases and summation of all cases. (a) Viral mRNA expression in each case. There were some differences in the proportion of $E 4, E 5 a$, and $E 5 b$ expression. However, these 3 mRNAs were predominant compared with the other mRNAs examined. (b) Proportion of mRNA expression. E4 was the most prevalent gene among the 9 viral mRNAs.

The correlations of the expression levels of each mRNA with the other viral mRNAs are shown in Table 4, examined by Spearman's rank-order correlation. The levels of all 9 viral mRNAs were significantly correlated to the levels of the other mRNAs.

Table 4. Correlation coefficients between the expression levels of the 9 viral mRNAs in HPV-6-related LP.

\begin{tabular}{|c|c|c|c|c|c|c|c|c|c|}
\hline & $E 6$ & $E 7$ & $E 1$ & $E 2$ & $E 4$ & $E 5 a$ & $E 5 b$ & $L 2$ & L1 \\
\hline E6 & - & $0.786^{* * *}$ & $0.757^{* * *}$ & $0.754^{* * *}$ & $0.807^{* * *}$ & 0.498 * & $0.705^{* * *}$ & $0.650 * * *$ & $0.577 * * *$ \\
\hline E7 & $0.786^{* * *}$ & - & $0.794^{* * *}$ & $0.882^{* * *}$ & $0.858^{* * *}$ & $0.649 * *$ & $0.942^{* * *}$ & $0.789 * * *$ & $0.838^{* * *}$ \\
\hline E1 & $0.757^{* * *}$ & $0.794^{* * *}$ & - & $0.853^{* * *}$ & $0.780 * * *$ & $0.845^{* * *}$ & $0.766^{* * *}$ & $0.944^{* * *}$ & $0.745^{* * *}$ \\
\hline$E 2$ & $0.754^{* * *}$ & $0.882 * * *$ & $0.853^{* * *}$ & - & $0.861^{* * *}$ & $0.721^{* * *}$ & $0.872^{* * *}$ & $0.819 * * *$ & $0.743^{* * *}$ \\
\hline$E 4$ & $0.807^{* * *}$ & $0.858^{* * *}$ & $0.780 * * *$ & $0.861^{* * *}$ & - & $0.554^{* * *}$ & $0.828^{* * *}$ & $0.705^{* * *}$ & $0.710^{* * *}$ \\
\hline$E 5 a$ & $0.498 *$ & $0.649 * *$ & $0.845^{* * *}$ & $0.721^{* * *}$ & $0.554^{* * *}$ & - & $0.6965^{* * *}$ & $0.904^{* * *}$ & $0.814^{* * *}$ \\
\hline$E 5 b$ & $0.705^{* * *}$ & $0.942 * * *$ & $0.766^{* * *}$ & $0.872^{* * *}$ & $0.828^{* * *}$ & $0.6965^{* * *}$ & - & $0.781^{* * *}$ & $0.922 * * *$ \\
\hline$L 2$ & $0.650^{* * *}$ & $0.789 * * *$ & $0.944^{* * *}$ & $0.819^{* * *}$ & $0.705^{* * *}$ & $0.904^{* * *}$ & $0.781^{* * *}$ & - & $0.806^{* * *}$ \\
\hline L1 & $0.577^{* * *}$ & $0.838^{* * *}$ & $0.745^{* * *}$ & $0.743^{* * *}$ & $0.710^{* * *}$ & $0.814^{* * *}$ & $0.922^{* * *}$ & $0.806^{* * *}$ & - \\
\hline
\end{tabular}

The correlations between viral DNA load and the levels of the 9 viral mRNAs were also examined by Spearman's rank-order correlation (Table 5). Viral DNA load showed positive correlations with E5a and $L 2$ mRNA levels ( $E 5 a, \mathrm{r}=0.507, p=0.0267 ; L 2, \mathrm{r}=0.542$, $p=0.0165$ ), and also tended to show positive correlations with E1 and L1 mRNA levels, although these relationships did not reach statistical significance $(E 1, \mathrm{r}=0.449, p=0.0536$; $L 1, r=0.436, p=0.0619)$. In contrast, there was no correlation between viral DNA load and the mRNA levels of E6,E7,E2, E4, and E5b ( $\mathrm{r}<0.4, p>0.05)$.

\subsubsection{Viral Load Alteration and Levels of the 9 Viral mRNAs in LP during 80 Months}

Viral load and the expression of the 9 viral mRNAs were measured in case 10, who undertook 10 revision surgeries over a period of 80 months. The levels of the 9 viral mRNAs and viral load altered synchronously with each other's peaks at 0,35 , and 71-73 months, with the lowest levels at 25 and 63 months (Figure 4). The shape of the mRNA expression curve resembled that of HPV-6 viral load. The Derkay score showed a different curve from viral mRNA levels and viral load. 
Table 5. Correlation coefficients between the levels of the 9 viral mRNAs and viral load in HPV-6related LP.

\begin{tabular}{ccc}
\hline mRNA & $\mathbf{r}$ & $p$-Value \\
\hline$E 6$ & 0.237 & 0.3289 \\
$E 7$ & 0.277 & 0.2506 \\
$E 1$ & 0.449 & 0.0536 \\
$E 2$ & 0.395 & 0.0944 \\
$E 4$ & 0.323 & 0.1777 \\
$E 5 a$ & 0.507 & $0.0267^{*}$ \\
$E 5 b$ & 0.374 & 0.1150 \\
$L 2$ & 0.542 & $0.0165^{*}$ \\
$L 1$ & 0.436 & 0.0619 \\
\hline
\end{tabular}

*p<0.05.

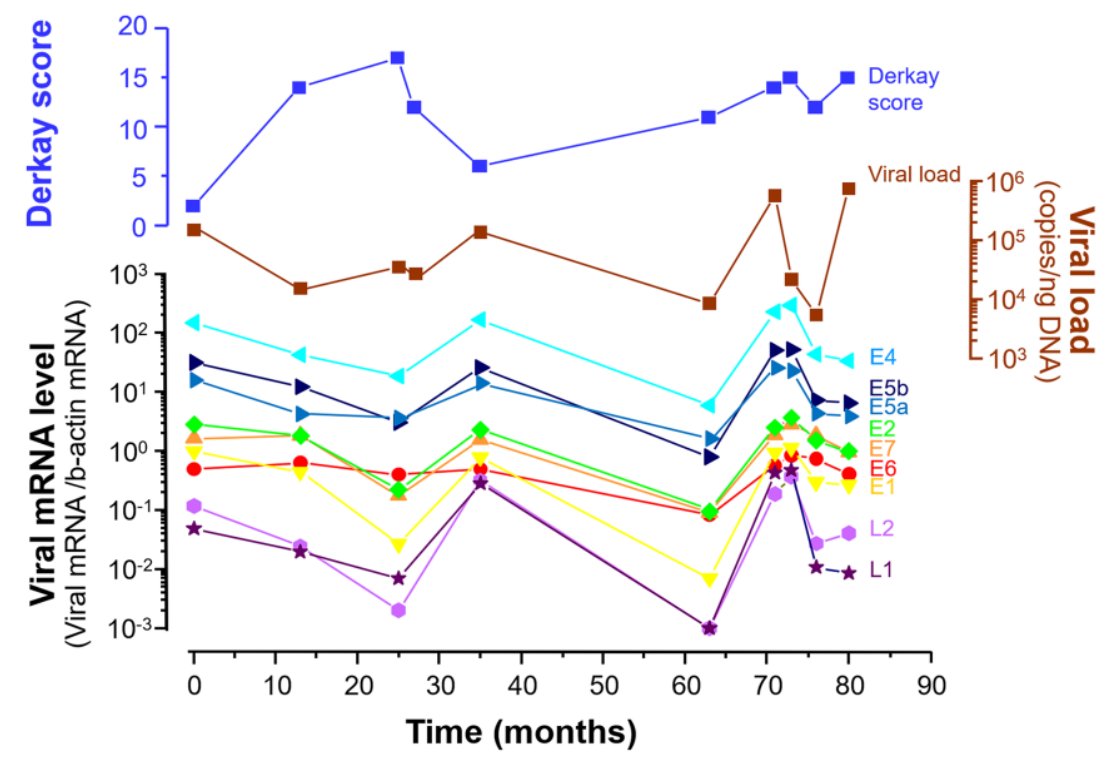

Figure 4. Alteration of mRNA levels, DNA viral load and Derkay score during long-term observation in patient 10. The viral DNA load alteration curve was similar to the mRNA expression curve.

\subsubsection{HPV-6 E6, E2, E4, E5a, and E5b mRNA Expression in LP Detected by RNA-ISH}

RNA-ISH with anti-sense probes showed that $E 4, E 5 a, E 5 b, E 6$, and $E 2$ signals were observed in 91.7\% (11/12), 75\% (9/12), 50.0\% (6/12), 41.7\% (5/12), and 41.7\% (5/12) of LP cases, respectively (Table 3 ).

RNA-ISH demonstrated that E4 and E5a mRNAs were strongly detected and located especially in the cytoplasm of the upper third cell layer of LP (Figure 5). Meanwhile, $E 2$ mRNA was expressed in the nuclei of the lower to upper third cell layer. E5b and E6 mRNAs were sparsely expressed in the cytoplasm and nuclei of the upper third cell layer, respectively.

Double fluorescence RNA-ISH showed that E4 (green signal) and E5a (pink signal) mRNAs had a similar distribution pattern, and the merged image of $E 4$ and $E 5 a$ showed that they were co-expressed in LP (Figure 6a). Double fluorescence RNA-ISH also showed that $E 4$ and $E 5 b \mathrm{mRNAs}$ had a similar distribution pattern, and the merged image of $E 4$ and $E 5 b$ showed that they were also co-expressed in LP (Figure $6 b$ ). These E4, E5a, and E5b mRNAs were observed dominantly in the upper third cell layer of LP. 


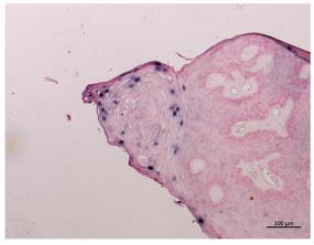

(a)

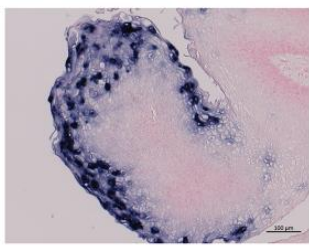

(d)

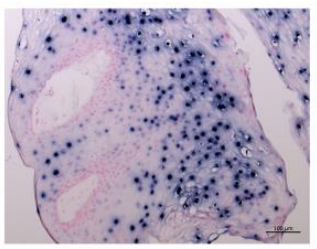

(b)

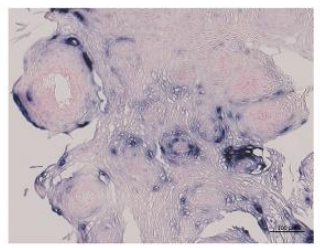

(e)

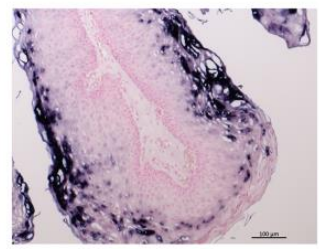

(c)

Figure 5. HPV mRNA expression in LP by RNA-ISH. Representative mRNA expression of (a) E6; (b) $E 2 ;$ (c) $E 4 ;$ (d) $E 5 a ;($ e) $E 5 b . E 4$ and $E 5 a$ were markedly expressed in the upper third of LP. Bar $=100 \mu \mathrm{m}$.

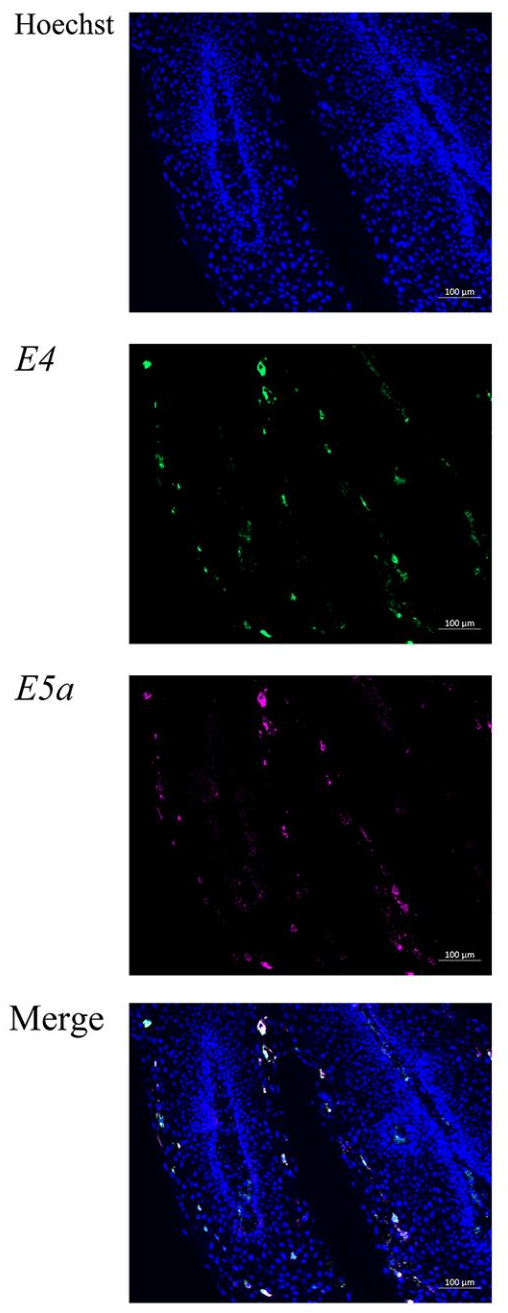

(a)

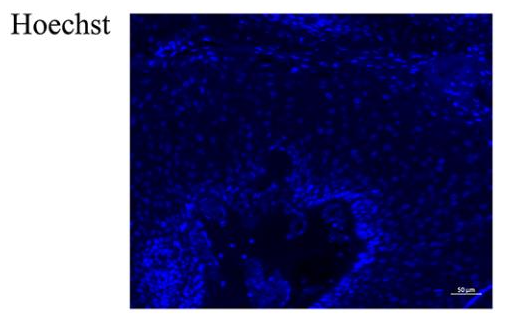

E4

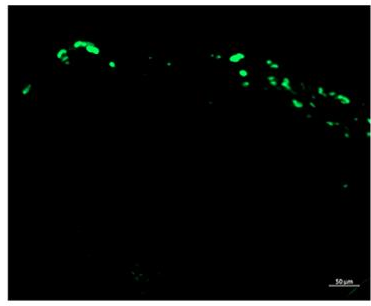

$E 5 b$
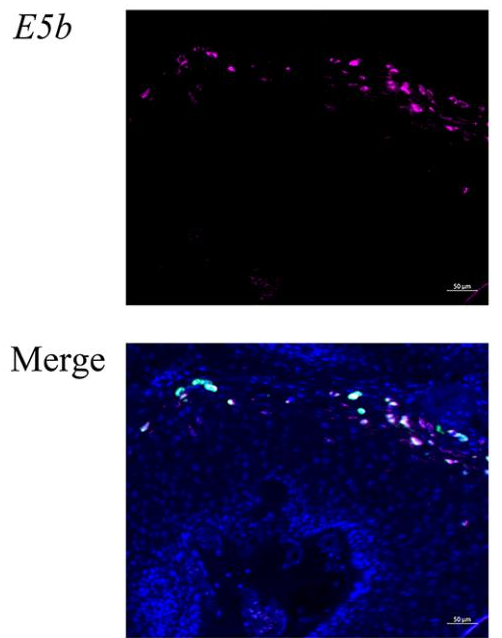

(b)

Figure 6. $E 4$ and $E 5 a$, and $E 4$ and $E 5 b$ expression detected by double fluorescence RNA-ISH. (a) Double staining of $E 4$ and $E 5 a$ in LP (bar $=100 \mu \mathrm{m})$. (b) $E 4$ and $E 5 b$ in LP (bar $=50 \mu \mathrm{m}) . E 4$ and $E 5 a$ and $E 4$ and $E 5 b$ mRNAs were co-expressed in the same LP cells. 


\subsection{Immunohistochemistry for $H P V-6 E 1^{\wedge} E 4$}

The newly developed monoclonal antibody against HPV-6 E1^E4 was validated by western blot analysis. Western blot analysis revealed that the anti-HPV-6 E1^E4 antibody bound only to HPV-6 E1^E4-3× FLAG fusion protein (13 kDa), but not to HPV-11 E1^E4-3× FLAG fusion protein, human CMTM7-3 × FLAG fusion protein, or lysate proteins from HEK293T cells (Figure S1 in the Supplementary Materials).

Immunohistochemistry for HPV-6 E1^ $E 4$ generated a positive reaction in the upper third of LP cell layer, similar to E4 RNA-ISH expression (Figure 7a,b). In contrast, HPV11-infected LP did not show a positive reaction with this anti-HPV-6 E1^ $E 4$ antibody (Figure 7c,d), but did show a positive reaction with a rabbit polyclonal anti-HPV-11 E1 ${ }^{\wedge} E 4$ antibody generated by ourselves (data not shown).

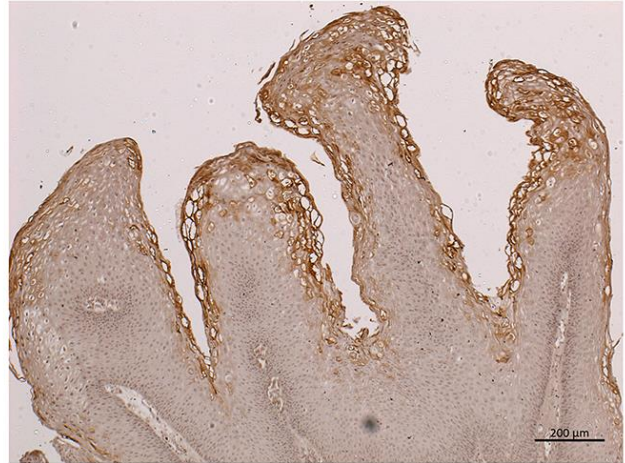

(a)

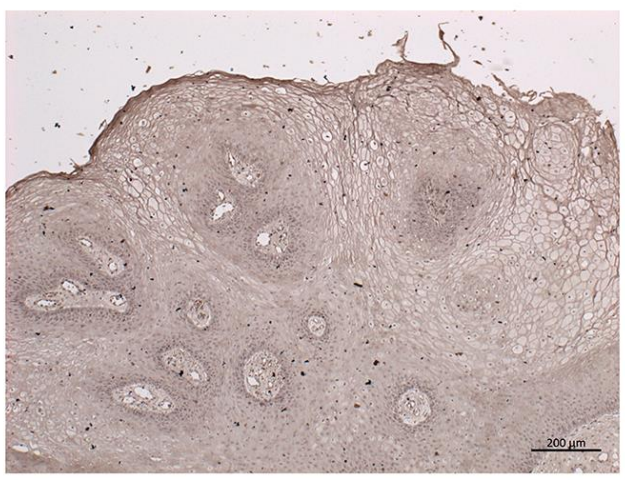

(c)

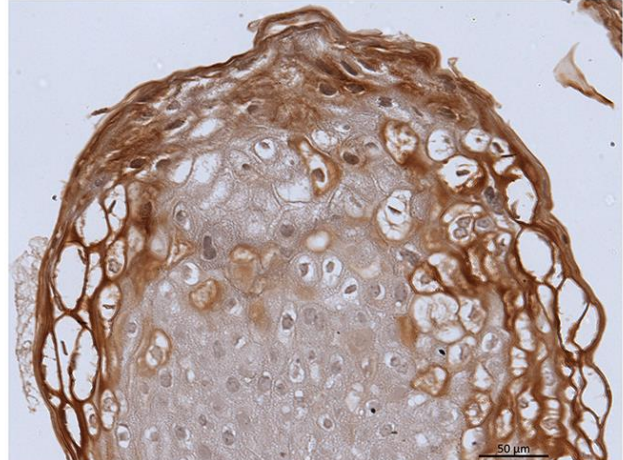

(b)

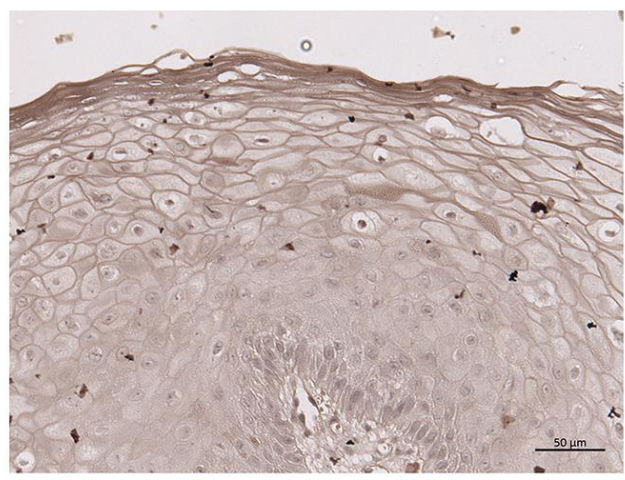

(d)

Figure 7. Immunohistochemistry for HPV-6 E4 in HPV-6-infected $(\mathbf{a}, \mathbf{b})$ and HPV-11-infected (c,d) LP. (a) Immunohistochemistry for HPV-6 E4 (low magnification) in HPV-6-infected LP (bar $=200 \mu \mathrm{m}$ ). (b) Immunohistochemistry for HPV-6 E4 (high magnification) in HPV-6-infected LP $($ bar $=50 \mu \mathrm{m})$. (c) Immunohistochemistry for HPV-6 E4 (low magnification) in HPV-11-infected LP (bar $=200 \mu \mathrm{m})$. (d) Immunohistochemistry for HPV-6 E4 (low high magnification) in HPV-11infected LP $($ bar $=50 \mu \mathrm{m})$. Strong immunoreactivity was observed in $(\mathbf{a}, \mathbf{b})$, but there were no positive reactions in $(\mathbf{c}, \mathbf{d})$.

\section{Discussion}

According to a recent investigation of the global genomic diversity of HPV-6, HPV-6a belongs to sublineage B3, HPV-6b is lineage A, and HPV-6vc is sublineage B1 [21]. In 176 LP samples, $21.6 \%$ were HPV-6 lineage A, 47.2\% were HPV-6 sublineage B1, and 17\% were HPV-6 sublineage B3 [21]. In the present study, HPV-6 subtypes were successfully determined in 11 LP samples, showing 3 with HPV-6a, 2 with HPV-6b, and 6 with HPV-6vc. The distribution of HPV-6 subtypes in the present study is consistent with this previous report [21]. The transcriptional activity of the LCR is significantly higher in sublineage B1 
with single nucleotide polymorphisms than in other B1 LCR variants [22]. Of the subtypes of HPV-6, HPV-6vc infection was observed in 2 cases with recurrence. Frequent recurrence of LP is a consequence of the long-term persistence of an identical initial HPV genomic variant [23]. Further study is needed to confirm the relationship between recurrence and HPV subtype or single nucleotide polymorphisms.

$E 4, E 5 a$, and $E 5 b$ mRNAs were exclusively expressed in the present study and represented $96 \%$ of the total expression of 9 HPV- 6 mRNAs. The results suggest that these 3 genes are the most important for the HPV-6 life cycle. E4 protein, which has significant sequence heterogeneity between HPV types, may play an essential role in the virus escape step from the epithelial surface and reflects the different tropisms and transmission routes of different papillomaviruses [10,24]. E4, E5a, and $E 5 b$ were expressed in the middle to upper part of the epithelium and were co-expressed in the same cells, as observed using double fluorescence RNA-ISH. These results suggest that $E 4, E 5 a$, and $E 5 b$ work cooperatively for viral replication, virus release, and immunosurveillance avoidance. Although information for the DNA-ISH probe is not available, the DNA-ISH results in the present study showed that the cells expressing HPV-6 DNA were located in all LP layers, especially the middle to upper part of the tumor, in accordance with $E 4, E 5 a$, and $E 5 b \mathrm{mRNA}$ expression. This observation also supports the above assumption related to $E 4, E 5 a$, and $E 5 b$. Therefore, E4, E5a, and E5b, showing predominant expression in HPV-6-associated LP, are good candidates as therapeutic molecules in LP.

Recently, the raft culture method of LP was reported, and there was no significant relationship between E1,E6,E7, L1, and L2 mRNA expression and viral load [25]. Although these results are inconsistent with our findings, the gene expression levels of $E 1, E 6, E 7, L 1$, and $L 2$ were much lower than those of $E 4$ and $E 5$ in the present study. These differences need to be clarified in the near future.

Previous studies regarding the functional roles of HPV-16 E4 and E5 reported that E4 could destroy HPV-infected cells, and E5 has a role in viral DNA synthesis and escape from immune surveillance [26]. HPV E5 is a small, membrane-bound, highly hydrophobic protein, and the $E 5$ gene is conserved in many HPVs [27]. The function of $E 5$ has been investigated primarily in HPV-16, and it plays a vital role in the HPV life cycle by delaying normal epithelial cell differentiation, while maintaining cell cycle progression, enhancing the oncogenic ability of the significant transforming protein $E 7[14,27,28]$, and playing a role in immunoevasion $[27,29]$. However, the roles of $E 5 a$ and $E 5 b$ in HPV-6 remain unclear. Although the expression levels of the 9 viral mRNAs were correlated with each other in the present study (Table 4), viral DNA load was only correlated with E5a and L2 mRNA levels (Table 5). L2 binds to circular viral DNA to enable genome encapsidation. The strong expression of $E 5 a$ in the middle to upper part of LP suggests that $E 5 a$ has a crucial role in viral DNA replication.

In the present study, the long-term alteration of viral DNA load and mRNA expression were successfully measured in a patient with multiple instances of recurrence. The alteration of viral DNA load in patient 10 paralleled viral mRNA expression, and the expression of all mRNAs showed a similar alteration curve. These findings suggest that the expression of all mRNAs in human LP has a cooperative role in viral DNA synthesis to generate recurrent lesions.

An anti-HPV-6 E4 antibody was established in the present study because $E 4$ had the highest expression among the 9 viral mRNAs examined in LP. This is the first antibody for HPV-6 E4 that can be used for immunohistochemistry and Western blot analysis. The antibody did not react to any other HPV-related lesions, such as LP with HPV-11 infection and oropharyngeal carcinoma with HPV-16 infection (data not shown). In the high-risk types of HPV, E4 protein assembles into amyloid fibrils that can disrupt the keratin network and compromise the normal assembly of the cornified envelope [10]. Although not yet defined precisely, E4 amyloid fibers in low-risk HPV may contribute to virion release from the upper epithelial layers, and therefore affect infectivity and transmission [30]. E4 immunohistochemistry demonstrated an extensively positive reaction in the upper cell 
layer in LP, in accordance with E4 mRNA expression. These results suggest that $\mathrm{E} 4$ has a role in virus release from LP and contributes to viral transmission. All LP samples with HPV-6 infection showed a strong positive reaction in the upper cell layer. These findings suggest that the $E 4$ immunohistochemistry can be used for the detection of HPV-6 infection. Since the functional role of $E 4$ is not understood fully, this antibody will help in the analysis of neoplastic development and the viral life cycle in low-risk HPV.

\section{Conclusions}

In the present study, we examined the HPV DNA viral loads, expression levels of 9 viral mRNAs, and cellular distribution of mRNA expression in 13 LP patients with HPV-6 infection ( 3 with HPV-6a, 2 with HPV-6b, 6 with HPV-6vc, and 2 with undetermined type). $E 4, E 5 a$, and $E 5 b$ mRNAs accounted for $96 \%$ of the expression of the 9 mRNAs. The alteration of viral DNA load during recurrence paralleled the mRNA expression levels, and the expression of all mRNAs showed a similar curve. E4, E5a, and E5b were expressed in the middle to upper part of the epithelium and were co-expressed in the same cells. E4 immunohistochemistry demonstrated an extensively positive reaction in the upper cell layer in accordance with $E 4$ mRNA expression. These results suggest that individual viral genes are coordinately expressed for viral replication, virus release, and immunosurveillance avoidance. However, there was no significant correlation between clinical parameters and viral load/HPV mRNA expression levels.

Supplementary Materials: The following are available online at https://www.mdpi.com/2076-2 607/9/3/520/s1, Figure S1: SDS-PAGE gel of cell lines and western blot analysis using anti-E1^E4 antibody; Table S1: Primers used in the present study; Table S2: Target gene, method, standard DNA, detection range, and amplification efficiency in real-time polymerase chain reaction (PCR).

Author Contributions: Conceptualization, T.I., M.S. and H.H.; methodology, T.I., N.T. and A.M.; software, T.I.; validation, M.S., T.K. and H.H.; formal analysis, T.I. and M.S.; investigation, T.I., N.H., N.T. and A.M.; resources, N.K., A.K., S.A., H.K., M.T., S.K. and H.M.; data curation, M.S. and A.G.; writing—original draft preparation, T.I. and T.K.; writing-review and editing, M.S. and A.G.; visualization, H.H.; project administration, T.I.; funding acquisition, T.I. All authors have read and agreed to the published version of the manuscript.

Funding: This study was supported by Grants-in-Aid for Early-Career Scientists (JSPS KAKENHI Grant Number 18K16896) to TI and Grant from the Construction of the Okinawa Science \& Technology Innovation System (Grant number 20E1000035) to TI.

Data Availability Statement: All data generated or analyzed during this study are included in this published article.

Acknowledgments: This study was supported by and conducted in cooperation with the Ryukyus Society for the Promotion of Oto-Rhino-Laryngology.

Conflicts of Interest: The authors declare no conflict of interest. The funders had no role in the design of the study; in the collection, analyses, or interpretation of data; in the writing of the manuscript, or in the decision to publish the results.

\section{References}

1. Fortes:, H.R.; von Ranke, F.M.; Escuissato, D.L.; Araujo Neto, C.A.; Zanetti, G.; Hochhegger, B.; Souza, C.A.; Marchiori, E. Recurrent respiratory papillomatosis: A state-of-the-art review. Respir. Med. 2017, 126, 116-121. [CrossRef]

2. Kanazawa, T.; Fukushima, N.; Imayoshi, S.; Nagamoto, T.; Kawada, K.; Nishino, H.; Ichimura, K. Rare case of malignant transformation of recurrent respiratory papillomatosis associated with human papillomavirus type 6 infection and p53 overexpression. SpringerPlus 2013, 2, 153. [CrossRef] [PubMed]

3. Schraff, S.; Derkay, C.S.; Burke, B.; Lawson, L. American society of pediatric otolaryngology members' experience with recurrent respiratory papillomatosis and the use of adjuvant therapy. Arch. Otolaryngol. Head Neck Surg. 2004, 130, 1039-1042. [CrossRef] [PubMed]

4. Baumann, J.L.; Cohen, S.; Evjen, A.N.; Law, J.H.; Vadivelu, S.; Attia, A.; Schindler, J.S.; Chung, C.H.; Wirth, P.S.; Meijer, C.J.L.M.; et al. Human papillomavirus in early laryngeal carcinoma. Laryngoscope 2009, 119, 1531-1537. [CrossRef] [PubMed] 
5. Doorbar, J.; Quint, W.; Banks, L.; Bravo, I.G.; Stoler, M.; Broker, T.R.; Stanley, M.A. The biology and life-cycle of human papillomaviruses. Vaccine 2012, 30 (Suppl. 5), F55-F70. [CrossRef]

6. Woodman, C.B.; Collins, S.I.; Young, L.S. The natural history of cervical hpv infection: Unresolved issues. Nat. Rev. Cancer 2007, 7, 11-22. [CrossRef]

7. Ribeiro, A.L.; Caodaglio, A.S.; Sichero, L. Regulation of hpv transcription. Clinics (Sao Paulo) 2018, 73, e486s. [CrossRef]

8. Graham, S.V. The human papillomavirus replication cycle, and its links to cancer progression: A comprehensive review. Clin. Sci. 2017, 131, 2201-2221. [CrossRef]

9. Egawa, N.; Doorbar, J. The low-risk papillomaviruses. Virus Res. 2017, 231, 119-127. [CrossRef]

10. Doorbar, J. The e4 protein; structure, function and patterns of expression. Virology 2013, 445, 80-98. [CrossRef]

11. Chen, J.; Xue, Y.; Poidinger, M.; Lim, T.; Chew, S.H.; Pang, C.L.; Abastado, J.P.; Thierry, F. Mapping of hpv transcripts in four human cervical lesions using rnaseq suggests quantitative rearrangements during carcinogenic progression. Virology 2014, 462-463, 14-24. [CrossRef] [PubMed]

12. Tsai, T.C.; Chen, S.L. The biochemical and biological functions of human papillomavirus type 16 e5 protein. Arch. Virol. 2003, 148, 1445-1453. [CrossRef]

13. Ilahi, N.E.; Bhatti, A. Impact of hpv e5 on viral life cycle via egfr signaling. Microb. Pathog. 2020, 139, 103923. [CrossRef]

14. Venuti, A.; Paolini, F.; Nasir, L.; Corteggio, A.; Roperto, S.; Campo, M.; Borzacchiello, G. Papillomavirus E5: The smallest oncoprotein with many functions. Mol. Cancer 2011, 10, 140. [CrossRef]

15. Ikegami, T.; Uehara, T.; Deng, Z.; Kondo, S.; Maeda, H.; Kiyuna, A.; Agena, S.; Hirakawa, H.; Yamashita, Y.; Ganaha, A.; et al. Detection of human papillomavirus in branchial cleft cysts. Oncol. Lett. 2018, 16, 1571-1578. [CrossRef]

16. Deng, Z.; Hasegawa, M.; Matayoshi, S.; Kiyuna, A.; Yamashita, Y.; Maeda, H.; Suzuki, M. Prevalence and clinical features of human papillomavirus in head and neck squamous cell carcinoma in okinawa, southern japan. Eur. Arch. Otorhinolaryngol. 2011, 268, 1625-1631. [CrossRef] [PubMed]

17. Deng, Z.; Ikegami, T.; Kiyuna, A.; Zhang, C.; Zhang, T.; Matayoshi, S.; Uehara, T.; Maeda, H.; Suzuki, M.; Ganaha, A. Methylation of cpg sites in the upstream regulatory region, physical status and mrna expression of hpv-6 in adult-onset laryngeal papilloma. Oncotarget 2017, 8, 85368-85377. [CrossRef] [PubMed]

18. Nakayama, H.; Murakami, A.; Yoshida, M.; Muraoka, J.; Wakai, J.; Kenjyou, N.; Ito, Y. Characterization and selection of 3-(1naphthoyl)-indole derivative-specific alpaca vhh antibodies using a phage display library. Monoclon. Antib. Immunodiagn Immunother 2016, 35, 231-234. [CrossRef]

19. Miyazaki, A.; Yogosawa, S.; Murakami, A.; Kitamura, D. Identification of cmtm7 as a transmembrane linker of blnk and the b-cell receptor. PLoS ONE 2012, 7, e31829. [CrossRef] [PubMed]

20. Derkay, C.S.; Hester, R.P.; Burke, B.; Carron, J.; Lawson, L. Analysis of a staging assessment system for prediction of surgical interval in recurrent respiratory papillomatosis. Int. J. Pediatr. Otorhinolaryngol. 2004, 68, 1493-1498. [CrossRef] [PubMed]

21. Jelen, M.M.; Chen, Z.; Kocjan, B.J.; Burt, F.J.; Chan, P.K.; Chouhy, D.; Combrinck, C.E.; Coutlée, F.; Estrade, C.; Ferenczy, A.; et al. Global genomic diversity of human papillomavirus 6 based on 724 isolates and 190 complete genome sequences. J. Virol. 2014, 88, 7307-7316. [CrossRef]

22. Szinai, M.; Nagy, Z.; Máté, P.; Kovács, D.; Laczkó, L.; Kardos, G.; Sápy, T.; Szúcs, A.; Szarka, K. Comparative analysis of human papillomavirus type 6 complete genomes originated from head and neck and anogenital disorders. Infect. Genet. Evol. 2019, 71, 140-150. [CrossRef]

23. Kocjan, B.J.; Gale, N.; Hočevar Boltežar, I.; Seme, K.; Fujs Komloš, K.; Hošnjak, L.; Maver, P.J.; Jelen, M.M.; Zupanič Pajnič, I.; Balažic, J.; et al. Identical human papillomavirus (HPV) genomic variants persist in recurrent respiratory papillomatosis for up to 22 years. J. Infect. Dis. 2013, 207, 583-587. [CrossRef]

24. Doorbar, J.; Egawa, N.; Griffin, H.; Kranjec, C.; Murakami, I. Human papillomavirus molecular biology and disease association. Rev. Med. Virol. 2015, 25 (Suppl. 1), 2-23. [CrossRef]

25. Bedard, M.C.; Brusadelli, M.G.; Carlile, A.; Ruiz-Torres, S.; Lodin, H.; Lee, D.; Kofron, M.; Lambert, P.F.; Lane, A.; Ameziane, N.; et al. Patient-derived organotypic epithelial rafts model phenotypes in juvenile-onset recurrent respiratory papillomatosis. Viruses 2021, 13, 68. [CrossRef] [PubMed]

26. Doorbar, J. Host control of human papillomavirus infection and disease. Best Pract. Res. Clin. Obstet. Gynaecol. $2018,47,27-41$. [CrossRef]

27. DiMaio, D.; Petti, L.M. The E5 proteins. Virology 2013, 445, 99-114. [CrossRef]

28. Faulkner, G.; Banks, L. The human papillomavirus (HPV)-6 and HPV-16 E5 proteins co-operate with HPV-16 E7 in the transformation of primary rodent cells. J. Gen. Virol. 1995, 76, 1239-1245.

29. Wlazlo, A.P.; Sparkowski, J.J.; Jenson, A.B.; Schlegel, R. Expression of the bovine papillomavirus type 1 E5b gene reveals a protein-protein interaction of the E5a and E5b gene products. Virology 2003, 307, 396-405. [CrossRef]

30. Griffin, H.; Soneji, Y.; Van Baars, R.; Arora, R.; Jenkins, D.; van de Sandt, M.; Wu, Z.; Quint, W.; Jach, R.; Okon, K.; et al. Stratification of HPV-induced cervical pathology using the virally encoded molecular marker E4 in combination with p16 or MCM. Mod. Pathol. 2015, 28, 977-993. [CrossRef] 